\title{
Saliva: A Healing Technique of Jesus in African Context.
}

\author{
T.O. Ebhomienlen and C. A. Ogah \\ Department Of Religious Management And Cultural Studies, Ambfose Alli University, Ekpoma Edo State \\ Nigeria
}

\begin{abstract}
This paper discusses saliva a healing technique of Jesus as contained in the canonical gospels in a bid to show its striking similarities with some healing methods and practices found in African societies. From this position the paper seeks to examine the use of saliva by Jesus in African perspective. It is hoped that this study will help to gain a better insight not only in the use of saliva as a healing technique in the Bible but also in African context. The writers adopt the historical, analytical, comparative and descriptive methodology to achieve the objectives of the paper. It is hoped that this study will form a bridge for cross-cultural pollination and integration, which is necessary for global development.
\end{abstract}

\section{Introduction}

Hoffman a Western scholar remarks that health is most precious of all things and is the foundation of all happiness, the science of protecting life and health is the noblest of all, and most worthy, the attention of all mankind. ${ }^{1}$ Therefore, "healing" the art of restoring health and maintaining and sustaining life is one of the greatest things. From, observation, experience and scientific discoveries, it has been realized that several materials in body are used as healing methods. For instance breast milk is important in the taking care of eye problems in children. There is a strong reference from many quarters to the use of urine as a therapeutic material. For instance among the Yorubas, urine is commonly recommended for a woman whose child experiences convulsion as a first aid treatment. Among the "Grain Massagers" exploiting the biblical reference in Proverbs 5: 15 that say "drink water from your cistern" have taken it to mean using the water that comes from one's own body to treat sicknesses. They use it for sicknesses like high blood pressure, cancer and so on. ${ }^{2}$ Human faeces are also exploited for psychosomatic purposes among the Esan people. Blood transfusion is another common bodily extracted material used for healing. However the main focus of this paper is on saliva. Thus studying "saliva" as a healing technique of Jesus is worthwhile as this will help to shed light on His entire healing ministry. Doing this study in African context helps to buttress the fact that the significance of Jesus ministry to African could be valued against the background of the importance of health and life. It is as a matter of fact, not less than a cross- cultural study which has been a goal of the social scientific approach to the study of the New testament as has been consistently championed by Bruce.J. Malina for about half a century now. According to him, a study of this kind is probably more helpful than some so called medical-Anthropological, psychological and political readings of Jesus' healing that has been embarked upon by some American scholars in recent years; in their tendency to explain them away as scientifically untenable. ${ }^{3}$

The study will help African Christians to appreciate more on the aspect of Jesus as a healer. It also shed light on the use of saliva in Africa as a healing method and thereby reveals the commonality in Christian and African traditional healing cultures.

Thus in the attempt of this paper, we shall deal with some selected traditional use of saliva as a healing technique as well as that of Jesus. Then we shall compare the two categories of healing methods, followed by the implication of the similarity of the two healing methods on the society where the religions operate.

\section{SALIVA}

Saliva has been defined as the fluid secreted by the salivary glands and discharged into the mouth cavity, which assists in mastication, swallow and digestion. ${ }^{4}$ According to Nabofa our experience among our own people, eye witness accounts from Africans and the study of African thought forms and religions practices have revealed some beliefs and symbolic cultic practice associated with saliva. In Africa, saliva is used for both positive and negative functions. It is an element into which multiracial hymnologies have been encoded with varied meaning decoded from it. ${ }^{5}$

The case is not different among the Jews from where the Christian religions emerged. Studies and experience have also revealed the importance of saliva symbolism among the Jews. Enough evidence is apparent in the Christian canonical Bible.

Chemical Contents In Salivary Gland And The Secretion Of Saliva. 
Before proceeding to our discussion, we feel that it is necessary to X-ray the chemical contents and functions of saliva, however brief and shallow it may be. Such will enable us to have a better understanding of the subject matter we shall discuss later.

\section{Contents}

According to Ganong, saliva contains the following: ${ }^{6}$

a) Ptyalin: This is an enzyme, which helps in the digestion of starch.

b) Musing: for lubrication purpose. It lubricates the food and aides swallowing.

c) Potassium.

d) Bicarbonate and

e) Sodium chloride-, which destroys bacteria. The last three chemicals contain factors that destroy bacteria; thus, they play major roles in oral hygiene during maximal salivary secretion. The sodium chloride content in saliva is said to be higher than other contents in saliva.

\section{Salivary Gland And Saliva}

In the salivary glands, the secretary (Zymogene) granules containing the salivary enzymes are discharged from the acute cells into the ducts. Saliva is said to contain the digestive enzymes and a glycoprotein that lubricates the food.

The chemical contents of saliva noted above enable it perform a number of important functions. It facilitates swallowing, keeps the mouth moist, serves as a solvent for the molecules that stimulate the task hugs, aids speech by facilitating movements of the lips and tongue, and keeps the mouth and teeth clean. Saliva also has some anti-bacterial function and patients with deficient salivation, which is known as xerostomia in medical term, have a higher than normal incidence of dental cavities. Saliva is saturated with calcium, and consequently the teeth do not lose calcium to the oral fruits. The buffers in saliva area also help to neutralize gastric acid and relieve heartburn when gastric juice is regurgitated into the esophagus.

\section{Control Of Saliva Secretion}

Secretion of saliva can be controlled: The secretion could be either increased or decreased. Practitioners of traditional medicines use items like alligator pepper to increase saliva secretion and bitter Kola to magnetize as well as strengthen the spiritual potency of such secretion. Hence in order to ensure a balanced secretion of saliva for ritual purpose these items are chewed together while performing some esoteric rites. ${ }^{7}$

It is possible to control salivary secretion because the production of saliva is under control. Stimulation of the parasympathetic nerve supply cause profuse secretion of water saliva with relatively low content of organic material. ${ }^{8}$.Associated with secretion is a pronounced vasodilatation in the gland, which appears to be due to the local release of vasoactive intestinal peptitude (V.I.P).

Ganong also explains that atropine and other cholinergic blocking agents reduce saliva secretion. Stimulation of the sympathetic nerves supplies cause vasoconstriction in human secretion of small amounts of saliva rich in organic constituents from the sub maxillary gland. Food in the mouth cause reflex secretion of saliva, and so does stimulation of vagal afferent fibres at the gastric end of the esophagus. Smell and even thought of food cause saliva secretion, and the mouth will become watery. ${ }^{9}$

The salivary glands contain somatostatin glucagons, and at least, in some species, rennin and various growth factors. The functions of most of these factors in the salivary glands are not known, but it has been digested that glucagons secreted from the salivary gland contributes to the hypergly caemiain pancreatectomized animals. As it has been earlier observed, some digestive enzymes are found in the secretion of the salivary glands. ${ }^{10}$

It is the mouth that food or any other things being eaten is mixed with saliva and propelled into the oesophagus. Peristaltic wave in the gullet moves with the eaten into the stomach. Mastication breaks up large food particles and mixed what has been chewed with secretion of the salivary glands. It is this welting that aids subsequent digestion. Apart from the above its chemical contents, saliva is also believed to embody some spiritual potencies, which cannot be empirically verified. This belief informed the way people handle and use it as discussed here.

\section{Relation Of Saliva To Life}

Several beliefs are associated with saliva, especially that of the human being. It is common beliefs that man's life is bound up in his saliva just as his life is believed to have been bound up in his blood. In fact it is regarded as the lubricant of life. ${ }^{11}$ This can be seen from its chemical contents and functions as explain above. When it is not flowing in the mouth, pharynx and oesophagus, such a person is not able to breathe properly and such will herald the end of his life. In fact when one is sick his gullet and pharynx get dry fast it is a warning that the life of such patient will soon come to an end. Even when those who are healthy suddenly notice that 
their throats are getting dried up, ordinarily such is taken as a serious warning from expiring untimely. Saliva is thus the lubricant of the channel of feeding and life.

In consequence of the fact that saliva lubricates and sustains life, it is conceived as life itself in several places in Africa. ${ }^{12}$ Therefore follows that the rituals performed with sputum are paralleled to the blood rites, though considered to be milder. Hence whatever is done with saliva is conceived as an externalization of man's personality.

The transfer and exchange of saliva, as discussed here, is considered to be more than a mere gifted or exchange of a portion of the spatter's life. Rather, as Crook opined: "it is a full and whole hearted gift or the spatter's life, which is put into the power of the recipient as a pledge of good-will." ${ }^{13}$ Actually it is a bodily union with the recipient, symbolically dramatized, just like the one that can be affected by a blood covenant. Therefore in a situation where two parties, exchange saliva, it is regarded as a milder form of blood covenant. ${ }^{14}$

\section{Saliva As A Means Of Healing By Jesus}

Jesus also made use of material "means" to effect healing in some occasions from the evidence of the gospel narrative. Jesus made use of spittle or saliva in some of the healing cases reported of him (John 9:6; Mark 7:33;8:23). In one of such cases, he even made a paste of saliva and clay, which he applied to the eyes of a blind man (John9:6). He most likely used oil, too. Although no case of this is extant in the gospel narratives, his disciples did make use of it in a missionary tour that He commissioned (Mark6:13 cf. Luke10:34). Jesus must have approved of the use since he sent then out. And this presupposes that he, too, was using it.

The use of both saliva and oil for therapeutic purposes can be found in the word of Jesus. "To spit" (PTUO) does not occur elsewhere in the second Testament. But "to spit upon" (E M P $\boldsymbol{T} \boldsymbol{U} \boldsymbol{O})$ is found six times in connection with the suffering of Jesus as a symbol of contempt. ${ }^{15}$ Contemptuous spitting was probably influenced by the first Testament, especially in Isaiah 50:6. No first Testament influence upon the second Testament use of spittle has, however been found ${ }^{16}$ Non-Biblical sources have pointed to the universal use of spittle for healing. Emperor Vespasian is reported to have healed a blind man with his spittle. ${ }^{17}$ the celebrated physical, Galen, is said to have recommended the saliva of a fasting human for healing. ${ }^{18}$ Indeed the use of spittle has been suggested to indicate a healing magic. ${ }^{19}$

In John 9:6, Jesus made clay with His spittle and anointed the Blind man's eyes and commanded him to go and wash in the pool of Siloam Jesus could not have anointed the blind man without a touch. The touch of a friendly hand would be reassuring the weight of the clay would indicate to the blind man that something had been done to him, and it would induce obedience to Jesus' command. Though his life-long affliction may have made him apathetic, he now had at least one motive for obeying.$^{20}$

The pool of Siloam was probably a considerable distance. His trip must have been a venture of faith. Jesus did not tell him that he would be healed but had merely commanded him to wash. ${ }^{21}$ He went, washed and came back seeing.

The significant things observed in this scenario are the question asked by the disciples who had connection with Exodus 34:76, which says “... visiting the iniquity of the father upon the children, and upon the children's children, unto the third and to the fourth generation" This, the Jews construed to mean that if a person suffered from any ailment, it must have been because his parents or grandparents had committed some sin against God. Likewise, the interplay of ritual, faith and water as methods of healing in Jesus' ministry underscore the fact that healing methods in Jesus' ministry and African perspective has something in common. The blind man underwent a process of what could be referred to as ritual cleansing before he received his sight. Jesus' action and command replaced the Jewish ritual cleansing which was necessary for an individual who broke a divine law.

Studies reveal that our immune system is designed to protect also redial us against harmful bacteria. It works to keep our normal micro flora in check and also eliminates invaders from outside the body. Some immune system defenses are built in: The skin acts as a barrier to bacterial invaders and ant-microbial substance in the body. Secretions such saliva and mucus can kill or stop the growth of some diseases causing bacteria. We acquire another immune system defense through exposure to diseases causing bacteria. ${ }^{22}$

Van Kesteron et al investigated antibacterial factors of human saliva, which is known to infect a wide variety of microorganism. By subjecting saliva to healing ultraviolet, storage, freezing and thawing, filtration, adsorption the chemical fractionation, the conclusion was reach saliva contain at least two antibacterial principles, the one resembling lysozyme; the other apparently being distinct from it. ${ }^{23}$

\section{Ritual Cleansing: The African Perspective}

In religious parlance impurity of any kind is believed to prevent the devotees from appearing in the presence of the divine, and such could cause problem not only for himself but also for the congregation of other worshippers that always seek to be in union with the divine. Consequently, if he realized that he has backslidden or broken a taboo he performs purification rites, which are believed to reunite him with the divine. There are 
several rituals all over African, which are used to achieve restoration with the divine and the expectoration of saliva is included in some of such rites. ${ }^{24}$

For example, as it obtains among the Urhobo and Isoko people if a person breaks any taboo or feels that he is not ritually pure, he is required to perform purification rites with the leaves of a shrub identified as ocimum. This shrub is known as oroan among the urhobo and Isoko. It has very strong aroma and its scent is believed to cleanse all impurities and attract good fortune and wholesomeness to man. ${ }^{25}$

The purification rites take the following forms: the person first holds this shrub in his right hand and goes to stand in an open space facing the sun or the main entrance of the compound. While standing thus he does a kind of confession and inward self-purgation. After such confession to the self and the ever present and omniscient God, he uses the small leafy branch to touch or sweep the different parts of his outer body while incanting an appropriate supplication which may take the following form:

It is cleansed.

All impurities are cleaned off.

Continuity of life is not cleansed away.

Longevity of life is not cleansed away

Children are not cleansed away.

Money / prosperity is not cleansed away.

Good health is not cleansed away.

Death is cleansed away.

Sickness is swept away.

Poverty is swept away.

Misfortune is swept away.

He does the above four times with his right hand and three times with his left. At the end of each round he stretches his hand holding the leafy branch forward, and spits breathily over it. At the completion of the seventh round he uses it to describe three circles round his head and cast it away following it with a contemptuous heavy expectoration. ${ }^{26}$

The belief is that once this is done the person no longer regards himself as ritually impure. It is not only the physical part of the man that has thus been cleansed but also his spiritual counterpart. In fact, it is traditionally believed that such expect oratory rituals have more direct effects on the soul personality which has been defiled than the physical body which could be washed clean with soap, sponge and water.

The heavy contemptuous expectoration is meant to eject impurities from his inward parts. The whole of his system has thus been cleansed. He has been purified and the door of salvation opened from his inner part. He is believed to be saved and enters the kingdom of eternal peace and bliss. With the leaf ofocimum or tea bush (oran) he was symbolically swept impurities from his physical and outer parts. And with expectoration he was purged from his inner self of all kinds of defilements. He has thus symbolically rejected both overt and converts impurities. He then considers himself purified and worthy to enter holy places. It is obligatory for traditional priests to carry out purification rituals before he goes to officiate in the shrine. Without that he does not consider himself ritually worthy and sacred enough to assume his priestly duties and play such roles.

The diviner also purifies his oracles, (oguega) at any time he went to divine for his clients with spittle. This saliva serves as means of introducing the divination instruments to the supra natural real in where hidden information could be obtained.

\section{Preparing Medicine And Charms}

Belief in the potency of saliva equally manifests itself in the area of medication and healing. Saliva is believed to be a very potent liquid and base for some kind of medicines and charms. In the practice of magic and traditional medicine people chew certain roots, herbs, nuts, fruits, mosses, and seeds such as bitter kola and alligator pepper and spew the juicy product on the body to either protect the person from harm or heal an ailing part of the body.

According to Nabofa, the Uwherun, a people in Ugbelli North Local Government Area of Delta state, Nigeria, for instance, hold a feast for an arch-divinity called Onidjor. The festival lasts for four days and the able bodied youth are the ones who take active part in the wrestling activities during the festival. The elders in each compound, extended family, and ward act as coaches, technical advisers and medicine men and woman for the contestants. ${ }^{27} \mathrm{~A}$ few hours before going to the wrestling area for the competition, the wrestlers are subjected to some special medication, the medicine:- man carryout and some divination and chew some charmed herbs and roots and spew the juicy substance around the chest and the back of each of the contesting wrestlers. Such is believed to endow the competitors with courage, strengths and protection against any form of external negative mysterious force and psychic attack. They are believed to be performance-enhancing charms. ${ }^{28}$ Some other herbs and roots are used in that way to protect one from bullets and wounds, from cuts, spear and clubs. This is 
quite similar to what Medea did for Jason. In Greek mythology, Madea, the arch- type Greek sorceress and witch protected Jason with this kind of medicine, which was in the form of an ointment that protected him against fire and metal. ${ }^{29}$ Such ingredients could, as well, have been pounded or ground somewhere else, mixed with water or some other liquid and applied to or rubbed on the body, as it is done in some other cases. But it is believed that such preparation may not produce the desired effects as when the materials have been chewed and, as it were, compounded with saliva. The ideal is that it is the psychic power of the saliva that enhances the potency and efficiency of such preparation.

Infact there are instances in which herbalists, compounding a medicine in a vessel is required to chew some of the ingredients such as alligator pepper, bitter kola, spices, mosses and herbs, and expectorate the juice mixed with masticated substance into the receptacle in which the other part of the medicine is being compounded. In some cases only the saliva may be required to be spat into the preparation. Whichever the case may be, all of the above is done in order to infuse the medicine with some extra efficacy which may come from the saliva.

Common experience and some practices have shown that saliva has a healing, cooling and soothing effect on minor scalds and ailing parts of the body. As we have earlier seen, saliva contains sodium chloride. The chewing of some substance such as alligator pepper, spices, herbs and heated moss enhances maximal salivary secretion it increases the constant of sodium chloride in the saliva and thus filled with a reasonable amount of energized antibiotics. Hence it is capable of soothing aches and pains and healing abrasion of the skin and wounds. The saliva of someone who has been fasting is believed to be heavily charged with those chemicals mentioned above, hence it is very potent. It is believed that the longer a fast lasts the more the potency of the person fasting. This experience and belief must have informed the practice of using the early morning saliva for must special rituals incantations and healing processes.

When, for instance a person comes very close to a hot object and physically contacts it, he spits on and rubs the affected part with some saliva. Infact such an act does serve as first aid. Saliva is even used in healing minor rashes and abrasions of the skin. As someone who grew up from rural area, It is observed that some people treat old wounds with saliva. After washing the sore, if it noticed that its surface is rough and moulds, in order to aid fast healing some experienced traditional healer breath heavily on its surface three times and allow drop of spit from the mouth fall on the wound. After that he puts the dressing herb on it. For instance, fresh bitter leaves mixed with saliva are rubbed together with the palms then the resulting juice is dropped on the surface of the sore. While the rubbed leaves are used to cover the sore surface. If the leaves are removing, saliva is still used to rub the sides of the leaves to stay it on the sore. After a few days of such treatment no matter how bad the sore may be, it normally shows some evidence of rapid healing, (provided of course there are no mysterious powers behind the festering wound). Even animals such as dogs and cats do heal their wounds with their own saliva by licking them constantly.

All these are pointers to the fact, that saliva really contains some germicides and yet unidentified properties which can heal some ailments. Saliva is also used for healing in so many other ways and this is not peculiar to traditional Africa. When Jesus Christ used his all-powerful and secreted saliva to compound a medicine and used it to heal the deaf and the dumb and even the blind (mark7:3-37), many African Christians understand very well what he did.

The efficacy of saliva also affords its being used as antiseptic. For example, when a poisonous insect, such as a wasp, stings one tsetse fly or even a mosquito, the person spontaneously spit on his hand and rubs the saliva on the affected area. Excrements from a spittlebug, birds and insects are believed to contain some poisonous larvae ${ }^{30}$. Consequently, when such droppings fall on a person he rubs the spot affected with some saliva. The belief is that in so doing the saliva neutralizes any poisonous element contained in either the sting or the droppings. Saliva is thus conceived and used as a natural and a God given antiseptic. It is with the power of sodium chloride contained in it that enables it to act as an effective antiseptic against such bacteria.

It also functions as a very potent neutralizer of all form of negative influence. Many people are seen expectorating on their urine and, where possible step on it. Such acts are symbolic. Spitting on the urine is not only a mark of rejection of the negativity associated with it, which emanates there from, but is also done to neutralize the negativity and sever the connection between it and its source, the person who had the urine. It is believed that once such is done whoever takes the urine for an evil intention will not succeed in harming the owner.

\section{Comparism}

A glance at the Jesus and African use of saliva as a healing method reveals some area of similarity and of course some divergence. Yet both similarity and divergence portray some significance for the Africa Christian vis-à-vis their understanding of the healing of Jesus.

\section{Similarities}


The belief in Jesus as a mediator and healer corroborates the belief of divinities and ancestors and mediator and healers in Africans traditional Religion. It is not news or special information to the African that ancestors and divinities are regarded as important intermediaries or mediators between human and God. ${ }^{31}$

The use of means is also common to both the Africans and the Christians, for instance the use of saliva which is the subject matter of the paper. Also, ritual washing is common in both healing cultures, Jesus made clay with spittle and just, put it on the blind man's eyes and prescribed to him that he should go and wash in river for full recovery of sight, this involved ritual washing as obtained in African religion.

\section{Divergence}

The skin difference is that Jesus did not employ saliva as a rigid method of healing rather it was an occasional application. In Jesus ministry saliva symbolizes cleansing and recreation by divine virtue. The healing potency lays in Jesus the healer while in African the healing potent is believed to be in saliva itself which can be used by an herbal man or by an individual as the occasion calls for.

\section{The Implication On The Church And Society}

The use of means as a method of healing by Jesus and in African healing culture is an asset to the church and the society. When x-rayed together it helps the African conceptualization of Jesus as a great healer and mediator. This enables us to see him as a "deified Ancestor" per excellence. The African Christians have composed songs depicting his power as "super power". Furthermore it also helps to enhance the use of materials for therapeutic purpose. Jesus made clay with spittle and dust, applied it for healing the blind. The Africa healing methods involve the use of natural material for the protection and preservation of life this corroborates the healing method of Jesus which ignorant Christians and others detractors in the society should not disregard. Jesus employed means as method therefore Africa traditional medical Practitioners should learn from this kind gesture instead of giving up their efforts, Jesus as a compassionate healer is enough legacies for them. Many Christians who are "informed" now practice and apply means for healing and protection of life. There are also several books these days revealing various ways of healing ailments by the use of the natural materials in our environment. The Pax Herbal in Ewu, Edo State should be commended for breaking a fallow ground in this respect.

\section{Conclusion}

In candid Jesus' healing techniques have a close affinity with African healers. Jesus made use of what was available to make His healing Ministry a reality. He did not invent his healing techniques. They were methods, which were available in the Jewish culture, which is the background of Christianity. He made use of those techniques for the bliss of human as whole. Basically the goal of healing in African is to make human whole so that they will be able to discharge their duties without any hindrance. Therefore any healing technique that does not abuse humanity and God's glory is worthwhile. Such should be encouraged and practiced so as to provide human salvation, which is the ultimate goal of human here and hereafter.

\section{References}

[1]. Hoffman in C.A. Dime, African Traditional Medicine: Peculiarities (Ekpoma: University Publishing House, 1994$), 34$.

[2]. Information form a Grain Messenger who prefers to be anonymous

[3]. S. L. Daves Jesus the Healer: Possession, Trance and the origins of Christianitycited in O. E. Alana "The Healing Techniques of Jesus in African context" African Journal of Biblical Studies, Vol. XXl l Nol (April, 2006) 24

[4]. J. Drever, A Dictionary of Psychology, (London: penquin Reference Books 1963)251.

[5]. M.Y. Nabofa "Saliva Symbolism in African Belief" ORITA: Ibadan Journal of Religious Studies Vol. XXV111/1-2, (June \& December 1996).

[6]. W. F. Ganong, Review of Medical Physiology $10^{\text {th }}$ Ed. (London: Prentice-Hall International 1987)391,406

[7]. Information from F. O. Okoh at Irrua on $12^{\text {th }}$ June, 2011.

[8]. M.Y.Nabofa Symbolism in African Traditional Religion (Ibadan: Paper Back Publishers Ltd 1994).55ff.

[9]. Ganong, 391,406.

[10]. Ganong

[11]. Nabofa

[12]. Nabofa

[13]. W. Crook "Saliva", in Encyclopedia of Religion and Ethics, Edited by James Hastings, X1, 100. 1958.

[14]. M.Y. Nabofa "Blood Symbolism in African Religion," in Religion Studies(Cambridge: University Press, 1984) 389-405.

[15]. J.M. Hull; Hellenistic Magic, And The Synoptic Tradition (London: SCM, 1974),76.

[16]. F.W. Beare, The Earliest Records of Jesus (Oxford: Oxford University Press 1972),135.

[17]. Hull, 76.

[18]. H. Van der Loos, The Miracles, of Jesus (Leiden: Brill, 1965)309.

[19]. R.M. Grant, A Historical introduction to the New Testament (New York: Simon \& Schuster, 1972$), 323$.

[20]. K.L. Barker \& J. R. Kohlenberger 111, Expositor's. Bible commentary (New Testament) (Michigan: Zonder van, 1994)327,328.

[21]. Barker and Kohlenberger, 328.

[22]. "Saliva" in Encarta Premium DVD (Assessed 25 ${ }^{\text {th }}$ August, 2011.

[23]. Van Keateron et al, "Saliva" in Encarta Premium DVD (Assessed 25 ${ }^{\text {th }}$ August, 2011). 
[24]. This aspect of the paper is taken from M.Y. Nobofa "Saliva symbolism in African Belief" Orita, Ibadan Journal of Religious Studies XXV111 1-2 (June \& December 1996),20.

[25]. Nabofa, 38 .

[26]. Nabofa, 39

[27]. Nabofa, 39

[28]. Nabofa, 39

[29]. . M. Nicholas, Man, Myth and Monuments, (New York: OUP, 1975)237 and G. S. Kirk, Myth: Its Meaning \& Functions (Cambridge: Longman 1970) 160-161.

[30]. Information from G.O. Ebhomienlen, Uromi 23/08/2011.

[31]. E.B. Idowu Olodumare God in Yoruba Belief (Lagos: Longman, 1996) 198-201 